1995

\title{
Azidotetrakis(trimethylphosphine)nickel(II) Tetrafluoroborate
}

Caryn C. Carson

Robert D. Pike

Follow this and additional works at: https://scholarworks.wm.edu/aspubs

Part of the Chemistry Commons 


$\begin{array}{lllll}\text { C11 } & 0.2981(3) & 0.2041(2) & 0.8102(2) & 0.056(1) \\ \text { C12 } & 0.0060(3) & 0.2667(2) & 0.8044(2) & 0.059(1) \\ \text { C1 } & 0.0171(9) & 0.1395(8) & 0.5228(7) & 0.042(5) \\ \text { C2 } & 0.1346(10) & 0.1806(8) & 0.5079(7) & 0.047(6) \\ \text { C3 } & 0.3567(10) & 0.2630(8) & 0.5915(7) & 0.046(6) \\ \text { C4 } & 0.4024(12) & 0.3295(9) & 0.6589(7) & 0.052(7) \\ \text { C5 } & 0.4930(12) & 0.3954(10) & 0.6429(10) & 0.054(8) \\ \text { C6 } & 0.5324(11) & 0.3972(10) & 0.5680(10) & 0.074(8) \\ \text { C7 } & 0.4855(11) & 0.3326(10) & 0.5056(8) & 0.061(7) \\ \text { C8 } & 0.3966(12) & 0.2681(9) & 0.5187(7) & 0.055(5) \\ \text { C9 } & 0.2873(9) & 0.0495(8) & 0.6173(7) & 0.045(6) \\ \text { C10 } & 0.2465(12) & -0.0124(8) & 0.6757(8) & 0.068(7) \\ \text { C11 } & 0.2767(13) & -0.1130(10) & 0.6793(9) & 0.074(8) \\ \text { C12 } & 0.3508(12) & -0.1514(9) & 0.6295(9) & 0.066(8) \\ \text { C13 } & 0.3875(15) & -0.0909(11) & 0.5708(13) & 0.102(11) \\ \text { C14 } & 0.3533(14) & 0.0119(10) & 0.5658(12) & 0.102(11) \\ \text { C15 } & -0.0863(9) & 0.3299(8) & 0.5661(7) & 0.043(5) \\ \text { C16 } & -0.1414(13) & 0.3391(8) & 0.4836(8) & 0.057(7) \\ \text { C17 } & -0.1842(14) & 0.4323(11) & 0.4532(9) & 0.083(9) \\ \text { C18 } & -0.1792(14) & 0.5127(10) & 0.5040(14) & 0.093(11) \\ \text { C19 } & -0.1273(14) & 0.5065(9) & 0.5857(10) & 0.070(8) \\ \text { C20 } & -0.0781(13) & 0.4137(8) & 0.6154(8) & 0.069(7) \\ \text { C21 } & -0.1506(9) & 0.1410(8) & 0.6391(8) & 0.046(6) \\ \text { C22 } & -0.2615(11) & 0.1867(9) & 0.6427(9) & 0.061(7) \\ \text { C23 } & -0.3503(12) & 0.1332(12) & 0.6665(11) & 0.085(9) \\ \text { C24 } & -0.3341(12) & 0.0319(12) & 0.6893(12) & 0.094(10) \\ \text { C25 } & -0.2286(15) & -0.0114(10) & 0.6848(10) & 0.088(9) \\ \text { C26 } & -0.1375(11) & 0.0431(9) & 0.6589(9) & 0.065(7) \\ & & & & \end{array}$

Table 2. Selected geometric parameters $\left(\AA,^{\circ}\right)$

\begin{tabular}{|c|c|c|c|}
\hline $\mathrm{Pd}-\mathrm{Cl1}$ & $2.415(3)$ & $\mathrm{Pd}-\mathrm{Cl} 2$ & $2.394(3)$ \\
\hline $\mathrm{Pd}-\mathrm{Pl}$ & $2.284(3)$ & $P d-P 2$ & $2.264(3)$ \\
\hline $\mathrm{P} 1-\mathrm{Cl}$ & $1.85(1)$ & $\mathrm{P} 2-\mathrm{C} 2$ & $1.87(1)$ \\
\hline $\mathrm{C} 1-\mathrm{C} 2$ & $1.56(2)$ & $\mathrm{P} 1-\mathrm{C} 15$ & $1.81(1)$ \\
\hline $\mathrm{P} 1-\mathrm{C} 21$ & $1.85(1)$ & $\mathrm{P} 2-\mathrm{C} 3$ & $1.89(1)$ \\
\hline $\mathrm{P} 2-\mathrm{C} 9$ & $1.84(1)$ & & \\
\hline $\mathrm{Cl} 2-\mathrm{Pd}-\mathrm{Cll}$ & $95.8(1)$ & $\mathrm{C} 15-\mathrm{P} 1-\mathrm{Pd}$ & $116.6(3)$ \\
\hline $\mathrm{P} 1-\mathrm{Pd}-\mathrm{Cl} 2$ & $87.6(1)$ & $\mathrm{C} 15-\mathrm{P} 1-\mathrm{C} 1$ & $107.5(5)$ \\
\hline $\mathrm{P} 1-\mathrm{Pd}-\mathrm{Cl} 1$ & $172.4(1)$ & $\mathrm{C} 18-\mathrm{C} 19-\mathrm{C} 20$ & $119(1)$ \\
\hline $\mathrm{C} 2-\mathrm{P} 2-\mathrm{Pd}$ & $106.5(4)$ & $\mathrm{P} 1-\mathrm{C} 21-\mathrm{C} 22$ & $123(1)$ \\
\hline $\mathrm{C} 9-\mathrm{P} 2-\mathrm{Pd}$ & $113.0(4)$ & $\mathrm{C} 22-\mathrm{C} 21-\mathrm{C} 26$ & $118(1)$ \\
\hline $\mathrm{P} 2-\mathrm{Pd}-\mathrm{Cl} 2$ & $175.5(1)$ & $\mathrm{C} 22-\mathrm{C} 23-\mathrm{C} 24$ & $119(1)$ \\
\hline $\mathrm{P} 2-\mathrm{Pd}-\mathrm{Cll}$ & $88.5(1)$ & $\mathrm{C} 24-\mathrm{C} 25-\mathrm{C} 26$ & $123(1)$ \\
\hline $\mathrm{P} 2-\mathrm{Pd}-\mathrm{P} 1$ & $88.3(1)$ & $\mathrm{C} 9-\mathrm{P} 2-\mathrm{C} 3$ & $107.0(5)$ \\
\hline C3-P2-Pd & $120.2(4)$ & $\mathrm{C} 21-\mathrm{P} 1-\mathrm{Pd}$ & $114.9(4)$ \\
\hline $\mathrm{C} 2-\mathrm{P} 2-\mathrm{C} 3$ & 105.1 (5) & $\mathrm{C} 21-\mathrm{Pl}-\mathrm{Cl}$ & $106.4(5)$ \\
\hline $\mathrm{C} 9-\mathrm{P} 2-\mathrm{C} 2$ & $103.5(5)$ & $\mathrm{C} 15-\mathrm{Pl}-\mathrm{C} 21$ & $106.5(5)$ \\
\hline $\mathrm{Cl}-\mathrm{P} 1-\mathrm{Pd}$ & $104.3(3)$ & & \\
\hline
\end{tabular}

Data were corrected for Lorentz and polarization factors. The structure was solved by direct methods with SHELXS86 (Sheldrick, 1985). The structure was refined using SHELX76 (Sheldrick, 1976). H atoms were fixed geometrically. The perspective view of the title molecule was drawn using ORTEPII (Johnson, 1976) and geometrical analysis was performed using PARST (Nardelli, 1983).

Lists of structure factors, anisotropic displacement parameters, $\mathrm{H}$ atom coordinates and complete geometry have been deposited with the IUCr (Reference: MU1120). Copies may be obtained through The Managing Editor, International Union of Crystallography, 5 Abbey Square, Chester CH1 2HU, England.

\section{References}

Bakir, M., Fanwick, P. E. \& Walton, R. A. (1987). Polyhedron, 6, 907-913.

Cromer, D. T. \& Mann, J. B. (1968). Acta Cryst. A24, 321-324.

Johnson, C. K. (1976). ORTEPII. Report ORNL-5138. Oak Ridge National Laboratory, Tennessee, USA.

Lewis, D. J., Luck, R. L. \& Silverton, J. V. (1993). Acta Cryst. C49, 1424-1426.

Nardelli, M. (1983). Comput. Chem. 7, 95-98.

Sheldrick, G. M. (1976). SHELX76. Program for Crystal Structure Determination. Univ. of Cambridge, England.

Sheldrick, G. M. (1985). SHELXS86. Program for the Solution of Crystal Structures. Univ. of Göttingen, Germany.

Steffen, W. L. \& Palenik, G. J. (1976). Inorg. Chem. 15, 24322438.

Wilkinson, G. (1951). J. Am. Chem. Soc. 73, 5502.

Acta Cryst. (1995). C51, 595-598

\section{Azidotetrakis(trimethylphosphine)nickel(II) Tetrafluoroborate}

\author{
Caryn C. Carson and Robert D. Pike* \\ Department of Chemistry, College of William and \\ Mary, Williamsburg, Virginia 23187, USA
}

\section{GENE B. CARPENTER}

Department of Chemistry, Brown University, Providence, Rhode Island 02912, USA

(Received 20 June 1994; accepted 15 September 1994)

\begin{abstract}
The title complex, $\left[\mathrm{Ni}\left(\mathrm{N}_{3}\right)\left(\mathrm{C}_{3} \mathrm{H}_{9} \mathrm{P}\right)_{4}\right] \mathrm{BF}_{4}$, is a nearly perfect trigonal bipyramid with the azide group at an apical position. The metal-azide bond angle, Nil$\mathrm{N} 1-\mathrm{N} 2$, of $138.6(5)^{\circ}$ is the largest observed for a terminal azide ligand.
\end{abstract}

\section{Comment}

Nickel(0) and nickel(I) reagents have significant utility in aryl-coupling reactions (Zembayashi, Tamao, Yoshida \& Kumada, 1977; Semmelhack et al., 1981; Rollin, Troupel, Tuck \& Perichon, 1986; Amatore \& Jutand, 1988; Zhou \& Yamamoto, 1991). A potential source of such low-valency metal complexes are metal azides. This results from the ability of the azide to undergo photo-induced reductive elimination. As part of a study of nickel-azide-phosphine complexes, the azidotetrakis(trimethylphosphine)nickel(II) cation was synthesized as its $\mathrm{BF}_{4}^{-}$salt, (1), and examined by X-ray crystallography. To our knowledge, this species is the only known five-coordinate nickel-azide complex.

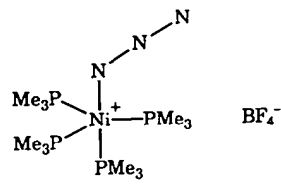

(1) ISSN 0108-2701 @ 1995 
The title complex is a dark violet solid which is soluble in polar organic solvents, as well as in water. In solution the complex readily dissociates a phosphine ligand, as evidenced by changes in the electronic spectrum $(391,556 \mathrm{~nm}$ bands are replaced by one at $463 \mathrm{~nm}$ ) and the IR spectrum (asymmetric azide stretch at $2062 \mathrm{~cm}^{-1}$ is replaced by $2053 \mathrm{~cm}^{-1}$ ). The solid may be stored in a sealed container below room temperature, but loses trimethylphosphine above $273 \mathrm{~K}$ over a period of several weeks.

Five-coordinate Ni complexes are not abundant, but most of those which are known exhibit approximate trigonal bipyramidal (tbp) geometry. Distortion from tbp geometry is very slight in the present case, as indicated by the N1-Ni1-P4 angle of $173.6(2)^{\circ}$. The metal atom lies 0.183 (1) $\AA$ from the equatorial plane defined by $\mathrm{P} 1, \mathrm{P} 2$ and $\mathrm{P} 3$, displaced toward $\mathrm{P} 4$. The point group symmetry of the cation is reduced from $C_{s}$ to $C_{1}$ since $\mathrm{N} 2$ and $\mathrm{N} 3$ of the azide ligand are neither eclipsed nor perfectly staggered with respect to the three equatorial $\mathrm{P}$ atoms. The $\mathrm{P} 3-\mathrm{Ni} 1-\mathrm{N} 1-\mathrm{N} 2$ dihedral angle is $-34.6^{\circ}$. Comparison of the overall geometry of $\left[\mathrm{Ni}\left(\mathrm{N}_{3}\right)\left(\mathrm{PMe}_{3}\right)_{4}\right] \mathrm{BF}_{4}$ with those of the related complexes $\left[\mathrm{NiBr}\left(\mathrm{PMe}_{3}\right)_{4}\right] \mathrm{BF}_{4}$ (Dartiguenave et al., 1978) and $\left[\mathrm{NiBr}\left\{\mathrm{P}(\mathrm{OMe})_{3}\right\}_{4}\right] \mathrm{BF}_{4}$ (Milbrath, Springer, Clardy \& Verkade, 1975) revealed that the bromide ligand in the previously reported nickel phosphine and phosphite structures assumes an equatorial position, while in the present case the azide ligand is axial. Bromide and azide ligands occupy similar positions in the spectrochemical series as a result of their similarity in electronegativity, nucleophilic constant and dipole moment (Patai \&

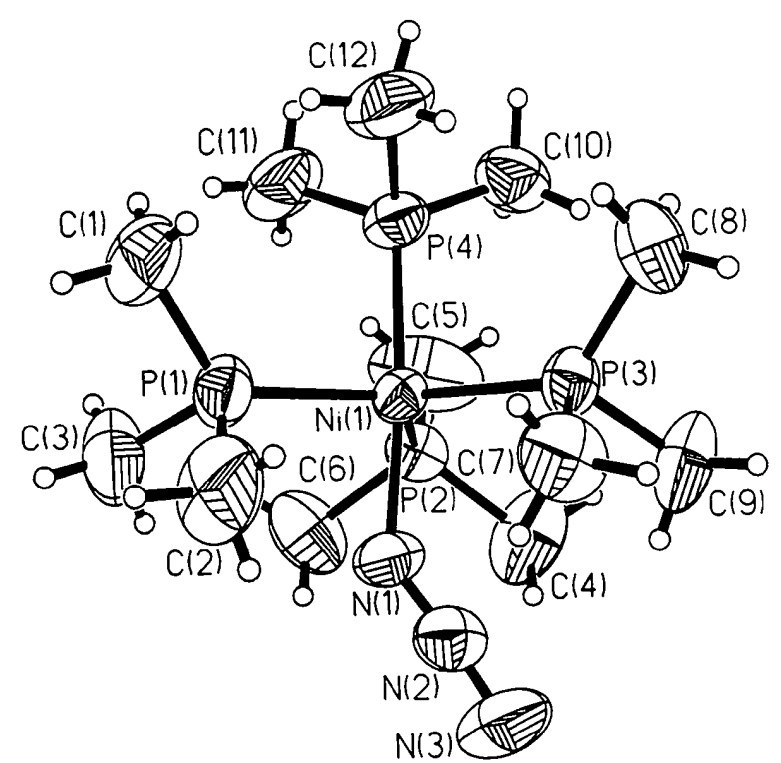

Fig. 1. View of the azidotetrakis(trimethylphosphine)nickel(II) cation. Displacement ellipsoids are shown at the $50 \%$ probability level. $\mathrm{H}$ atoms are shown with arbitrary radii.
Treinin, 1971). Theoretical calculations (Rossi \& Hoffmann, 1975) suggest that $\pi$-donor ligands (such as $\mathrm{Br}$ and $\mathrm{N}_{3}$ ) will prefer axial positions in $d^{8}$ tbp complexes. This is borne out only in the present case.

The azide group itself is nearly linear with $\mathrm{N} 1-$ N2-N3 $174.9(8)^{\circ}$. The Ni1-N1 distance of $1.929 \AA$ is somewhat short, but lies within the typical range of 1.93-2.12 ̊ (Dori \& Ziolo, 1973). It should be noted that axial bond lengths in tbp nickel complexes are typically a little shortened. The $\mathrm{N} 1-\mathrm{N} 2$ and $\mathrm{N} 2-$ N3 distances are also typical. However, the metalazide bond angle, $\mathrm{Ni} 1-\mathrm{N} 1-\mathrm{N} 2$, of $138.6(5)^{\circ}$ is quite unusual. The generally accepted range is $117-128^{\circ}$ (Dori \& Ziolo, 1973), although at least one significant outlier to this range is known: $\left[\mathrm{Cp}_{2} \mathrm{Ti}\left(\mathrm{N}_{3}\right)_{2}\right]$ (de Gil, de Burguera, Rivera \& Maxfield, 1977), where the Ti$\mathrm{N}-\mathrm{N}$ angle is $137^{\circ}$. In fact, the metal-azide bond angle in the present structure is, to our knowledge, the largest yet observed. This large metal-azide bond angle may be understood by examination of the contributing resonance structures (I)-(III):

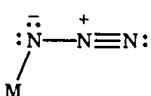

(I)<smiles>[M]N=[N+]=[N-]</smiles>

(II)

$$
\overline{\mathrm{M}}=\stackrel{+}{\mathrm{N}}=\stackrel{+}{\mathrm{N}}=\stackrel{-}{=} \cdot
$$

(III)
Since most metal-azide bond angles are around $120^{\circ}$, it is reasonable that form (II) (having $s p^{2}$ hybridization at the bound $\mathrm{N}$ atom) is usually dominant. On the other hand, the large metal-azide bond angle found in the title compound corresponds to a resonance hybrid between (II) and (III). Resonance form (III) results from nitrogento-nickel $\pi$ donation. The conclusion that the azide behaves as a strong $\pi$ donor in $\left[\mathrm{Ni}\left(\mathrm{PMe}_{3}\right)_{4}\left(\mathrm{~N}_{3}\right)\right]^{+}$is reasonable given the acceptor character of the phosphine ligands. The $\mathrm{Ni} 1-\mathrm{N} 1-\mathrm{N} 2$ bond angle may also be influenced by crowding from the phosphine ligands. Each of the three P4-Nil-PX $(X=1,2,3)$ angles is approximately $94-95^{\circ}$.

\section{Experimental}

Nickel tetrafluoroborate was prepared from nickel carbonate and $\mathrm{HBF}_{4} . \mathrm{Ni}\left(\mathrm{BF}_{4}\right)_{2}$ and $\mathrm{NaN}_{3}$ (1 mmol of each) were dissolved in about $10 \mathrm{ml}$ of $\mathrm{H}_{2} \mathrm{O}$. To this lime-green solution, $4 \mathrm{ml}$ of $1 M \mathrm{PMe}_{3}$ in tetrahydrofuran was added. Dark violet crystals precipitated and were collected after cooling the solution to $258 \mathrm{~K}$. Suitable single crystals were grown over several weeks at room temperature from a concentrated $\mathrm{CH}_{2} \mathrm{Cl}_{2}$ solution layered with hexanes in a $3 \mathrm{~mm}$ i.d. tube.

\section{Crystal data}

$\left[\mathrm{Ni}\left(\mathrm{N}_{3}\right)\left(\mathrm{C}_{3} \mathrm{H}_{9} \mathrm{P}\right)_{4}\right] \mathrm{BF}_{4}$

$M_{r}=491.84$

Mo $K \alpha$ radiation

$\lambda=0.71073 \AA$ 
Orthorhombic

Pbca

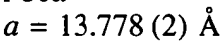

$b=13.2816$ (13) $\AA$

$c=26.188(3) \AA$

$V=4792.1(9) \AA^{3}$

$Z=8$

$D_{x}=1.363 \mathrm{Mg} \mathrm{m}^{-3}$

\section{Data collection}

Siemens $P 4$ diffractometer

Profile-fitted $\omega$ scans

Absorption correction: empirical

$T_{\min }=0.524, T_{\max }=$ 0.609

5242 measured reflections 4220 independent reflections 2018 observed reflections

$$
[I>2 \sigma(I)]
$$

\section{Refinement}

Refinement on $F^{2}$

$R\left[F^{2}>2 \sigma\left(F^{2}\right)\right]=0.0577$

$w R\left(F^{2}\right)=0.1337$

$S=1.106$

4220 reflections

232 parameters

$\mathrm{H}$ atoms refined as riding $w=1 /\left[\sigma^{2}\left(F_{o}^{2}\right)+(0.0743 P)^{2}\right]$ where $P=\left(F_{o}^{2}+2 F_{c}^{2}\right) / 3$
Cell parameters from 39 reflections

$\theta=2.15-25.0^{\circ}$

$\mu=1.109 \mathrm{~mm}^{-1}$

$T=298(2) \mathrm{K}$

Prism

$0.54 \times 0.38 \times 0.20 \mathrm{~mm}$

Dark violet

$R_{\text {int }}=0.0426$
$\theta_{\max }=25.00^{\circ}$
$h=-1 \rightarrow 16$
$k=-1 \rightarrow 15$
$l=-31 \rightarrow 1$

3 standard reflections frequency: $97 \mathrm{~min}$ intensity decay: none

$(\Delta / \sigma)_{\max }=-0.052$

$\Delta \rho_{\max }=0.657 \mathrm{e}^{-3}$

$\Delta \rho_{\min }=-0.633 \mathrm{e} \AA^{-3}$

Extinction correction: none

Atomic scattering factors from International Tables for Crystallography (1992, Vol. C, Tables 4.2.6.8 and 6.1.1.4)

Table 1. Fractional atomic coordinates and equivalent isotropic displacement parameters $\left(\AA^{2}\right)$

$U_{\text {iso }}$ for disordered $\mathrm{BF}_{4} ; U_{\text {eq }}=(1 / 3) \sum_{i} \sum_{j} U_{i j} a_{i}^{*} a_{j}^{*} \mathbf{a}_{i} \cdot \mathbf{a}_{j}$ for remainder.

$\begin{array}{lcccc} & x & y & z & U_{\text {iso }} / U_{\text {eq }} \\ \text { Ni1 } & 0.0554(1) & 0.1954(1) & 0.1057(1) & 0.045(1) \\ \text { P1 } & -0.0521(1) & 0.0847(2) & 0.1435(1) & 0.064(1) \\ \text { P2 } & 0.0447(1) & 0.2476(1) & 0.0221(1) & 0.054(1) \\ \text { P3 } & 0.2006(1) & 0.2210(1) & 0.1483(1) & 0.053(1) \\ \text { P4 } & -0.0137(1) & 0.3283(1) & 0.1353(1) & 0.061(1) \\ \text { N1 } & 0.1045(4) & 0.0742(4) & 0.0744(2) & 0.064(2) \\ \text { N2 } & 0.1775(5) & 0.0430(5) & 0.0588(2) & 0.066(2) \\ \text { N3 } & 0.2459(5) & 0.0070(6) & 0.0414(3) & 0.135(3) \\ \text { C1 } & -0.1307(6) & 0.1079(7) & 0.1977(3) & 0.104(3) \\ \text { C2 } & 0.0090(6) & -0.0275(6) & 0.1652(4) & 0.117(3) \\ \text { C3 } & -0.1370(5) & 0.0334(7) & 0.0972(3) & 0.105(3) \\ \text { C4 } & 0.1597(5) & 0.2487(7) & -0.0110(2) & 0.104(3) \\ \text { C5 } & -0.0031(7) & 0.3651(6) & -0.0028(3) & 0.127(4) \\ \text { C6 } & -0.0250(6) & 0.1607(6) & -0.0140(3) & 0.094(3) \\ \text { C7 } & 0.2418(5) & 0.1089(5) & 0.1797(3) & 0.087(2) \\ \text { C8 } & 0.2271(6) & 0.3115(5) & 0.1980(3) & 0.085(2) \\ \text { C9 } & 0.2988(5) & 0.2474(7) & 0.1035(3) & 0.094(3) \\ \text { C10 } & 0.0457(5) & 0.4435(5) & 0.1184(3) & 0.078(2) \\ \text { C11 } & -0.1383(5) & 0.3483(7) & 0.1138(3) & 0.097(3) \\ \text { C12 } & -0.0239(6) & 0.3390(7) & 0.2042(3) & 0.098(3) \\ \text { B1A } & 0.5877(13) & 0.1762(14) & 0.1749(7) & 0.091(3) \\ \text { F1 } 3 & 0.6431(9) & 0.2511(9) & 0.1930(5) & 0.125(5) \\ \text { F2A } & 0.6170(9) & 0.0885(9) & 0.1978(5) & 0.143(4) \\ \text { F3A } & 0.5931(11) & 0.1587(11) & 0.1241(4) & 0.164(5) \\ \text { F4A } & 0.4943(7) & 0.1954(8) & 0.1857(4) & 0.122(4) \\ \text { B1B } & 0.5961(14) & 0.1787(14) & 0.1687(7) & 0.091(3) \\ \text { F1B } & 0.6541(8) & 0.2595(8) & 0.1723(4) & 0.104(4) \\ \text { F2B } & 0.6433(8) & 0.1076(9) & 0.1402(5) & 0.134(4) \\ \text { F3B } & 0.5189(9) & 0.2053(9) & 0.1390(5) & 0.141(4) \\ \text { F4B } & 0.5706(10) & 0.1377(11) & 0.2148(4) & 0.161(5)\end{array}$

Table 2. Selected geometric parameters $\left(\AA,^{\circ}\right)$

$\begin{array}{lclc}\mathrm{Ni} 1-\mathrm{N} 1 & 1.929(6) & \mathrm{P} 2-\mathrm{C} 5 & 1.815(7) \\ \mathrm{Ni} 1-\mathrm{P} 4 & 2.152(2) & \mathrm{P} 3-\mathrm{C} 7 & 1.793(7) \\ \mathrm{Ni} 1-\mathrm{P} 2 & 2.301(2) & \mathrm{P} 3-\mathrm{C} 8 & 1.809(7) \\ \mathrm{Ni} 1-\mathrm{P} 1 & 2.309(2) & \mathrm{P} 3-\mathrm{C} 9 & 1.825(6) \\ \mathrm{Ni} 1-\mathrm{P} 3 & 2.316(2) & \mathrm{P} 4-\mathrm{C} 10 & 1.791(7) \\ \mathrm{P} 1-\mathrm{C} 2 & 1.804(8) & \mathrm{P} 4-\mathrm{C} 12 & 1.815(7) \\ \mathrm{P} 1-\mathrm{C} 1 & 1.812(7) & \mathrm{P} 4-\mathrm{Cl1} & 1.826(7) \\ \mathrm{P} 1-\mathrm{C} 3 & 1.817(7) & \mathrm{N} 1-\mathrm{N} 2 & 1.162(7) \\ \mathrm{P} 2-\mathrm{C} 6 & 1.773(7) & \mathrm{N} 2-\mathrm{N} 3 & 1.150(8) \\ \mathrm{P} 2-\mathrm{C} 4 & 1.806(7) & & \\ \mathrm{N} 1-\mathrm{Ni1}-\mathrm{P} 4 & 173.6(2) & \mathrm{N} 1-\mathrm{Ni1}-\mathrm{P} 3 & 91.4(2) \\ \mathrm{N} 1-\mathrm{Ni1}-\mathrm{P} 2 & 82.6(2) & \mathrm{P} 4-\mathrm{Ni}-\mathrm{P} 3 & 95.03(7) \\ \mathrm{P} 4-\mathrm{Ni1}-\mathrm{P} 2 & 93.89(7) & \mathrm{P} 2-\mathrm{Ni} 1-\mathrm{P} 3 & 118.02(7) \\ \mathrm{N} 1-\mathrm{Ni} 1-\mathrm{P} 1 & 82.9(2) & \mathrm{P} 1-\mathrm{Ni1}-\mathrm{P} 3 & 116.15(7) \\ \mathrm{P} 4-\mathrm{Ni1}-\mathrm{P} 1 & 94.80(8) & \mathrm{N} 2-\mathrm{N} 1-\mathrm{Ni} & 138.6(5) \\ \mathrm{P} 2-\mathrm{Ni1}-\mathrm{P} 1 & 123.95(7) & \mathrm{N} 3-\mathrm{N} 2-\mathrm{N} 1 & 174.9(8)\end{array}$

The structure was determined by Patterson methods and refined initially by use of programs in the SHELXTL/PC (Sheldrick, 1990) package, which was also used for the figure. The quality of the solution was compromised somewhat by disorder in the $\mathrm{BF}_{4}^{-}$ion. This disorder was modeled as two half-occupancy ions with individual isotropic displacement parameters, except for the parameters for the two B half-atoms which were constrained to be equal. All B-F distances were restrained to be similar with a standard deviation of $0.03 \AA$, as were all F...F distances within each ion. Only nine of the $\mathrm{H}$ atoms appeared in a difference map. Each $\mathrm{H}$ atom was introduced in an ideal position, riding on the atom to which it is bonded and refined with an isotropic temperature factor $20 \%$ greater than that of the parent atom. All other atoms were refined with anisotropic displacement parameters. The 12 methyl groups were allowed to rotate about their $\mathrm{P}-\mathrm{C}$ bonds. Final refinement on $F^{2}$ was carried out using SHELXL93 (Sheldrick, 1993).

Data collection: XSCANS (Siemens, 1993). Cell refinement: $X S C A N S$. Data reduction: XSCANS. Program(s) used to solve structure: SHELXTL/PC (Siemens, 1990). Program(s) used to refine structure: SHELXL93 (Sheldrick, 1993). Molecular graphics: SHELXTL/PC. Software used to prepare material for publication: SHELXL93.

Acknowledgement is made to the donors of the Petroleum Research Fund, administered by the American Chemical Society (PRF No. 26521-GB1), and to the College of William and Mary for support of this research. The X-ray equipment was purchased with assistance from an instrument grant from the National Science Foundation (CHE-8206423) and a grant from the National Institutes of Health $(R R-06462)$.

Lists of structure factors, anisotropic displacement parameters and $\mathrm{H}$-atom coordinates have been deposited with the IUCr (Reference: BK 1077). Copies may be obtained through The Managing Editor, International Union of Crystallography, 5 Abbey Square, Chester $\mathrm{CH} 1$ 2HU, England.

\section{References}

Amatore, C. \& Jutand, A. (1988). Organometallics, 7, 2203-2214. Dartiguenave, M., Dartiguenave, Y., Gleizes, A., Saint-Joly, C., Galy, J., Meier, P. \& Merbach, A. E. (1978). Inorg. Chem. 17, 3503-3512. Dori, Z. \& Ziolo, R. F. (1973). Chem. Rev. 73, 247-254. 
Gil, E. R. de, de Burguera, M., Rivera, A. V. \& Maxfield, P. (1977). Acta Cryst. B33, 578-579.

Milbrath, D. S., Springer, J. P., Clardy, J. C. \& Verkade, J. G. (1975). Inorg. Chem. 14, 2665-2668.

Patai, A. \& Treinin, A. (1971). In The Chemistry of the Azido Group. London: Interscience.

Rollin, Y., Troupel, M., Tuck, D. G. \& Perichon, J. (1986). J. Organomet. Chem. 303, 131-137.

Rossi, A. \& Hoffmann, R. (1975). Inorg. Chem. 14, 365-374.

Semmelhack, M. F., Helquist, P., Jones, L. D., Keller, L., Mendelson, L., Ryono, L. S., Smith, J. G. \& Stauffer, R. D. (1981). J. Am. Chem. Soc. 103, 6460-6471.

Sheldrick, G. M. (1990). SHELXTL/PC Users Manual. Siemens Analytical X-ray Instruments Inc., Madison, Wisconsin, USA.

Sheldrick, G. M. (1993). SHELXL93. Program for the Refinement of Crystal Structures. Univ. of Göttingen, Germany.

Siemens (1993). XSCANS. Version 2.00a. Siemens Analytical X-ray Instruments Inc., Madison, Wisconsin, USA.

Zembayashi, M., Tamao, K., Yoshida, J.-I. \& Kumada, M. (1977). Tetrahedron Lett. pp. 4089-4092.

Zhou, Z.-H. \& Yamamoto, T. (1991). J. Organomet. Chem. 414, 119 127.

Acta Cryst. (1995). C51, 598-600

\section{trans-Bis $\left(O, O^{\prime}\right.$-diethyl dithiophosphato- $\kappa^{2} S, S^{\prime}$ )bis(isoquinoline- $\kappa N$ )nickel(II)}

\section{XIAO-Ying HuANG}

State Key Laboratory of Structural Chemistry, Fujian Institute of Research on the Structure of Matter, Academia Sinica, Fuzhou 350002, People's Republic of China

\section{Ren-Gen Xiong and Jun-Xiu Dong}

Department of Chemistry and the State Key Laboratory of Structural Chemistry, Logistic Engineering College, Chongquing, 630042 Shicun, People's Republic of China

\section{XIaO-Zeng You}

Coordination Chemistry Institute and the State Key Laboratory of Structural Chemistry, Nanjing University, Nanjing, 210008 Jiangsu, People's Republic of China

(Received 13 April 1994; accepted 4 October 1994)

\section{Abstract}

In (OC-6-12)-bis $\left(O, O^{\prime}\right.$-diethyl dithiophosphato- $\left.\kappa^{2} S, S^{\prime}\right)$ bis(isoquinoline- $\kappa N)$ nickel(II), $\quad\left[\mathrm{Ni}\left(\mathrm{C}_{4} \mathrm{H}_{10} \mathrm{O}_{2} \mathrm{PS}_{2}\right)_{2}\right.$ $\left(\mathrm{C}_{9} \mathrm{H}_{7} \mathrm{~N}\right)_{2}$ ], a distorted $\mathrm{N}_{2} \mathrm{~S}_{4}$ octahedron is formed around the central $\mathrm{Ni}$ atom. Two $O, O^{\prime}$-diethyl dithiophosphate (dtp) ions act as bidentate ligands, each forming a four-membered chelate ring by coordination of its two $\mathrm{S}$ atoms in the equatorial plane. Two axial isoquinoline ligands are coordinated to the metal atom through their $\mathrm{N}$ atoms. The $\mathrm{Ni}-\mathrm{S}$ and $\mathrm{Ni}-\mathrm{N}$ bond distances are $2.507(2)-2.518(1) \AA$ and 2.118 (3) $\AA$, respectively.

\section{Comment}

The structures of the triphenylphosphine and pyridine adducts of (diethyl dithiophosphato)nickel(II) have been reported (Liu, Lin, Yu, Zhu, Xu, Gou \& You, 1991; Ooi \& Fernando, 1967). In [Ni $\left.\left\{\left(\mathrm{C}_{2} \mathrm{H}_{5} \mathrm{O}\right)_{2} \mathrm{PS}_{2}\right\}_{2}\left\{\mathrm{P}\left(\mathrm{C}_{6} \mathrm{H}_{5}\right)_{3}\right\}\right]$, the $\mathrm{Ni}$ atom displays square-pyramidal coordination (Liu et al., 1991), whereas octahedral metal coordination was found in $\left[\mathrm{Ni}\left\{\left(\mathrm{C}_{2} \mathrm{H}_{5} \mathrm{O}\right)_{2} \mathrm{PS}_{2}\right\}_{2}\left(\mathrm{C}_{5} \mathrm{H}_{5} \mathrm{~N}\right)_{2}\right]$ (Ooi \& Fernando, 1967). Crystals of the title compound, (I), are composed of discrete molecules (Fig. 1) and each $\mathrm{Ni}$ atom lies on a crystallographic centre of symmetry. Two dtp ligands are bonded to nickel by their two $S$ atoms, forming four-membered chelate rings in the equatorial plane; the octahedral coordination is completed by the $\mathrm{N}$ atoms of two isoquinoline ligands.

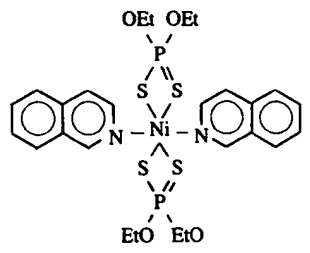

(I)

The $\mathrm{Ni}-\mathrm{S}$ distances [2.507(2) and $2.518(1) \AA]$ are slightly longer than those in $\left[\mathrm{Ni}\left\{\left(\mathrm{C}_{2} \mathrm{H}_{5} \mathrm{O}\right)_{2} \mathrm{PS}_{2}\right\}_{2}\right.$ $\left.\left\{\mathrm{P}\left(\mathrm{C}_{6} \mathrm{H}_{5}\right)_{3}\right\}\right]$ and $\left[\mathrm{Ni}(\mathrm{dtp})_{2}\right][2.43(3)$ and $2.21 \AA$, re-

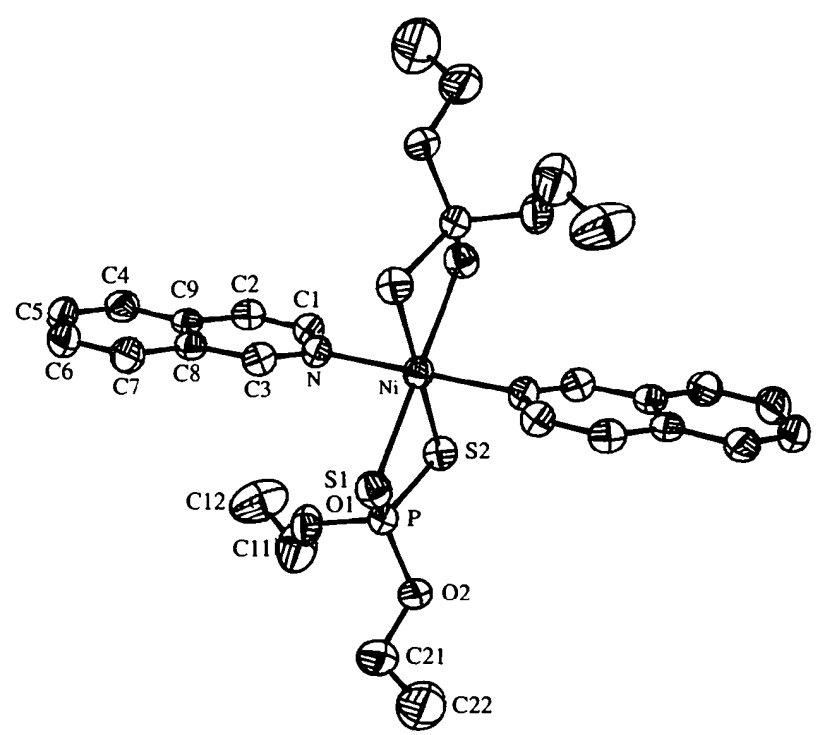

Fig. 1. Molecular structure (ORTEPII; Johnson, 1976) of the title complex showing $40 \%$ probability displacement ellipsoids. $\mathrm{H}$ atoms are omitted for clarity. 